\title{
Multicellular behaviour and production of a wide variety of toxic substances support usage of Bacillus subtilis as a powerful biocontrol agent
}

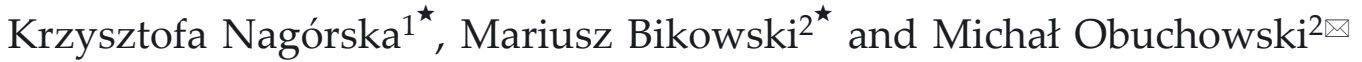 \\ ${ }^{1}$ Department of Molecular Biology, University of Gdańsk, Gdańsk, Poland; ${ }^{2}$ Department of Medical \\ Biotechnology, Intercollegiate Faculty of Biotechnology, Medical University of Gdańsk, Gdańsk, Poland
}

Received: 11 July, 2007; revised: 03 September, 2007; accepted: 13 September, 2007 available on-line: 17 September, 2007

\begin{abstract}
Intensive cultivation of plants in the monoculture field system in order to feed the continuously growing human population creates a need for their protection from the variety of natural competitors such as: bacteria, fungi, insects as well as other plants. The increase in the use of chemical substances in the 20th century has brought many effective solutions for the agriculture. However, it was extremely difficult to obtain a substance, which would be directed solely against a specific plant pathogen and would not be harmful for the environment. In the late 1900's scientists began trying to use natural antagonisms between resident soil organism to protect plants. This phenomenon was named biocontrol. Biological control of plants by microorganisms is a very promising alternative to an extended use of pesticides, which are often expensive and accumulate in plants or soil, having adverse effects on humans. Nonpathogenic soil bacteria living in association with roots of higher plants enhance their adaptive potential and, moreover, they can be beneficial for their growth. Here, we present the current status of the use of Bacillus subtilis in biocontrol. This prevalent inhabitant of soil is widely recognized as a powerful biocontrol agent. Naturally present in the immediate vicinity of plant roots, B. subtilis is able to maintain stable contact with higher plants and promote their growth. In addition, due to its broad host range, its ability to form endospores and produce different biologically active compounds with a broad spectrum of activity, B. subtilis as well as other Bacilli are potentially useful as biocontrol agents.
\end{abstract}

Keywords: biocontrol, Bacillus subtilis, multicellular behaviour, antimicrobial agents

\section{OVERVIEW}

Biological control of plants by microorganisms is a very promising alternative to the extended use of pesticides, which are often expensive and accumulate in plants, having adverse effects on humans. Such chemicals can also be lethal to the beneficial residents of soil (Leroux, 2003). Moreover, detection of undesirable chemical compounds in the food chain connected with the emergence of fungicide-resistant strains of pathogens (El-Ghaouth, 1997) calls for an alternative, non-polluting strategy for control- ling plant diseases. There is a significant number of rhizobacteria present in the soil, on average at $10^{8}$ cells/g (Priest, 1993). Nonpathogenic soil bacteria living in association with roots of higher plants enhance the adaptive potential of the hosts and increase their growth. In 1980, Kloepper called them Plant Growth-Promoting $\underline{R}$ hizobacteria (PGPR), to stress their beneficial effect on plants. PGPR have numerous traits, which allow them to act as biocontrol agents: suppression of diseases caused by phytopathogens thanks to the production of a wide range of antimicrobial compounds (Ongena et al.,

$\square$ Corresponding author: Michał Obuchowski, Department of Medical Biotechnology, Intercollegiate Faculty of Biotechnology, Medical University of Gdańsk, Dębinki 1, 80-211 Gdańsk, Poland; tel.: (48 58) 349 1412, fax: (48 58) 349 1445, email: obuchowk@biotech.ug.gda.pl

These authors made equal contribution to this work.

Abbreviations: EPS, exopolysaccharide; ISR, induced systemic resistance; PGPR, plant growth-promoting rhizobacteria; NRPS, non-ribosomal peptide synthetases. 
$2005 b)$, competition in colonization of the niche and for the nutrients with species non-stimulating for plant growth or even pathogenic (Bais et al., 2004; Timmusk et al., 2005), and activation of the host defense system by induced systemic resistance (ISR) (Ongena et al., 2005a). Plant stimulatory effects may be also achieved by an increased availability for the uptake from the soil of nutrients such as nitrogen, phosphorus, amino acids (Idriss et al., 2002).

For a long time, Gram-negative bacteria, especially Pseudomonas strains, have been intensively investigated as biological control agents (Kraus $\&$ Loper, 1995). However, recently the attention has switched to the Gram-positive members of the aerobic, spore-forming genus Bacillus. Among them, B. subtilis - a Gram-positive model organism (Moszer, 1998), and a prevalent soil inhabitant is now widely recognized as a powerful tool in biocontrol. As a soil-dwelling rhizobacterium, naturally present in the immediate vicinity of plant roots, B. subtilis is able to maintain stable contact with higher plants and promote their growth. In addition, due to its broad host range, its ability to form endospores and produce different antibiotics with a broad spectrum activity, B. subtilis as well as other members of Bacillus genus are potentially useful biocontrol agents.

\section{ANTIBIOTIC PRODUCTION - INVALUABLE WEAPON IN FIGHTING COMPETITORS}

According to the present state of knowledge, several mechanisms can explain the promotion of plant growth by bacteria existing in the rhizosphere. One of the major aspects of this stimulation is certainly the suppression of diseases caused by phytopathogens (Toure et al., 2004). Production of antimicrobial agents by PGPR plays here a principal role (Leclere et al., 2005). B. subtilis, the most common representative of the genus, has been found to have broad suppressive properties for more than 23 types of plant pathogens in vitro due to its ability to produce a great abundance of antibiotics with an amazing variety of structures and activities (Stein, 2005). Those compounds include predominantly peptides that are either of ribosomal origin or are generated non-ribosomally. The features which determines their effectiveness are the wide spectrum of action and resistance to hydrolysis by peptidases and proteases. Their activity is also resistant to high temperatures and a wide range of $\mathrm{pH}$ (Souto et al., 2004). All the genes involved in the antibiotic syntheses in B. subtilis combined amount to $350 \mathrm{~kb}$. However, as no strain has all of them, an average of about $4-5 \%$ of the B. subtilis genome is devoted to antibiotic production (Stein, 2005).
A major fraction of the B. subtilis antibiotics suppressing plant pathogens are non-ribosomally synthesized peptide derivatives, mainly lipopeptides. They are formed by large multienzymes - non-ribosomal peptide synthetases (NRPSs), which govern all necessary steps in their biosynthesis (Finking \& Marahiel, 2004). Their structures are highly flexible. Natural rearrangements occur very often in these systems, permitting natural selection of compounds that offer the selective advantage (Stein, 2005). Thus, NRPSs are easily accessible to genetic manipulations, providing powerful tools for generation of novel antibiotics with new properties (Sieber \& Marahiel, 2003). This might be a promising way for future development of new strategies in the field of biocontrol of plants.

Lipopeptides are amphipathic, cyclic antibiotics widespread in the Bacillus genus. Variations in length and branching of the fatty acid chains and amino-acid substitutions allow the lipopeptides identified so far to be divided into three groups: the surfactin (Peypoux et al., 1999; Mulligan, 2005), iturin (Tsuge et al., 2005) and fengycin families (Ongena et al., 2005b). They are composed of seven $\alpha$ amino acids (iturins and surfactins) or ten $\alpha$-amino acids (fengycins). The length of the fatty acid chains is also variable and ranges from C13 to C18 (Stein, 2005). Moreover, some lipopeptides are also produced with a huge diversity in length of the acyl side-chains, e.g.: fengycin A possesses isomers from C14 to C18 (Ongena et al., 2005b). It has been shown that lipopeptides with longer hydrocarbon side chains (C17 and C18) are potentially more bioactive (Toure et al., 2004). Their fungitoxicity increases with the number of carbon atoms in the fatty acid moiety, i.e., the $\mathrm{C} 17$ homologues are 20-fold more active than the C14 forms (Leclere et al., 2005). In the case of $B$. subtilis some of these antibiotics have been found to be produced by a great variety of strains, e.g. subtilosin A, sublancin. Others are expressed strain-specifically, for example, ericin is produced by B. subtilis A1/3 only (Stein et al., 2002). In addition, a wide range of antimicrobial substances is also produced by Brevibacillus brevis, B. licheniformis, B. pumilus (Munimbazi \& Bullerman, 1998), B. amyloliquefaciens (Souto et al., 2004), B. cereus, Paenibacillus polymyxa (Timmusk et al., 2005).

\section{THE VARIETY AND COMPLEXITY OF THE ITURINS AND FENGYCINS}

Lipopeptides from the iturin and fengycin families display a potent antifungal activity and suppress the growth of a wide range of plant pathogens (Toure et al., 2004). Iturins are produced by $B$. subtilis and other closely related Bacilli, e.g., B. amy- 
loliquefaciens (Souto et al., 2004). The iturin group comprises iturins A-E, bacillomycins D, F, and L, and mycosubtilin (Stein, 2005). Those molecules disrupt the yeast plasma membrane by forming small vesicles and by aggregating membrane-spanning particles. They also release electrolytes and high molecular mass products and degrade phospholipids. Members of the iturin family exhibit also a rather limited antibacterial activity (Maget-Dana \& Peypoux, 1994). Overproduction of mycosubtilin, one of the best known members of the iturin family, by a recombinant $B$. subtilis strain BBG100, has significant antagonistic properties against phytopathogenic fungi, Botrytis cinerea, Fusarium oxysporum and Pythium aphanidermatum, and yeasts, Pichia pastoris and Saccharomyces cerevisiae (Leclere et al., 2005). This strain is a derivative of B. subtilis ATCC6633 and has a 15fold higher mycosubtilin production rate than the parental strain. The authors demonstrated that pretreatment of tomato seeds with vegetative cells of the mycosubtilin-overproducing strain prior to planting in soil infected with $P$. aphanidermatum led to enhanced germination rates of seeds compared with the treatment with the wild-type strain ATCC6633. Besides the antifungal activities, mycosubtilin is also involved in Bacillus spreading. Leclere et al. (2006) demonstrated that overproduction of mycosubtilin is directly related to an enhanced invasive behaviour. Addition of the purified lipopeptide to the medium caused the enhance of swarming motility of B. subtilis 168, which is known as a non-spreading strain (Julkowska et al., 2004) (this phenomenon is described in a further part of the review). Numerous studies have shown the potential of the iturin family as alternative antifungal agents. B. amyloliquefaciens strain B94 suppresses Rhizoctonia solani and other fungal plant pathogens. Isomers of iturin A purified from culture broth were responsible for inhibition of $R$. solani growth in vitro. Moreover, Souto et al. (2004) indicated that those excreted secondary metabolites efficiently inhibited mycelia growth of $F$. oxysporum f. sp. lycopercisi, R. solani, Fusarium solani and Sclerotinia sclerotiorum.

Fengycins play an important role in plant disease reduction. Direct evidence derives from experiments of Ongena et al. (2005b), who showed the ability of B. subtilis strain M4, an important producer of a wide variety of fengycin-type lipopeptides, to protect wounded apple fruits against mold disease caused by B. cinerea.

\section{SURFACTANTS - WIDE-RANGING SURFACE- ACTIVE COMPOUNDS}

The group of biosurfactants (surface-active agents of microbial origin) are molecules that parti- tion preferentially at the interface between two phases, such as vapour and liquid interface. The reason that causes biosurfactants to localize at interfaces is that they are amphipathic, i.e., they contain both hydrophobic and hydrophilic moieties (Przestalski et al., 2000; Mulligan, 2005). What determines the effectiveness of surfactants is their ability to reduce the surface tension (Ron \& Rosenberg, 2001). Surfactin, the best known member of this group, is the most powerful biosurfactant ever discovered - a $20 \mu \mathrm{M}$ solution decreases the surface tension of water from 72 to $27 \mathrm{mN} \mathrm{m}^{-1}$ (Carrillo et al., 2003). For a long time a surfactin was the only lipopeptide with a proven surfactant capacity. Main producers include strains of B. subtilis, about 20 strains from private or public collections have been categorized as surfactin-positive (Peypoux et al., 1999). B. licheniformis and B. pumilus produce peptidic variants of surfactin, named lichenysin and pumilacidin, respectively (Naruse et al., 1990; Yakimov et al., 1996).

Naturally occurring surfactin is a mixture of different types of molecules, which are classified according to the variation in the chain length and branching of its $\beta$-hydroxy fatty acid as well as differences in amino-acid sequence (Kowall et al., 1998). Biosynthesis of surfactin is a property of bacteria from the genus Bacillus. Surfactin prevents platelet aggregation leading to an inhibition of fibrin clot formation (Lim et al., 2005), is also able to remove heavy metals from contaminated soil and sediments (Mulligan, 2005), increases solubilization and biodegradation of hydrophobic compounds. Recently it was found that the colonizing behaviour and biofilm formation of $B$. subtilis strains depend on production of different families of lipopeptides (Leclere et al., 2006). The architecture of the colony on a swarming medium as well as the flotation and the thickness of the pellicle formed at the air/liquid interface is influenced by the pattern of the lipopeptides produced. Generally, exolipids promote swarming motility but also influence biofilm structure. Leclere et al. (2006) showed that addition of a purified antifungal compound, mycosubtilin, enhanced the spreading of $B$. subtilis 168 on B-medium. The role of mycosubtilin in this process is based on an increase of the wettability and a decrease of the surface tension of the medium. This double activity could be considered as a synergistic effect towards phytopathogenic fungi in the field of biocontrol, by increasing the ability of the bacteria to colonize target surfaces, connected with the strong antifungal properties of mycosubtilin. An aspect of great importance, which seems to have a remarkable potential for biocontrol of plant diseases is the surfactin's antiadhesive properties (Ron \& Rosenberg, 2001). Surfactin exhibits strong antibacterial and antifungal properties. This is probably due to its capability of permeabilizing cellular 
membranes (Heerklotz \& Seelig, 2007). Surfactin displays an array of amazing activities, although the underlying mechanisms remain unclear and need to be established. Deciphering of the genetic organization of the operon responsible for surfactin synthesis, research of lipopeptide's molecular structure and chemical relationship between the residues are important advantages in capacity to engineer new modified compounds with improved properties. Thimon et al. (1994) described chemically modified (Glu- $\gamma$-methyl ester) surfactin with enhanced surface-active properties. Another interesting variant was achieved by replacing amino acids at positions 2, 4 and 7 with isoleucyl residues. This (lle-2, $-4,-7)$ surfactin had improved surfactant together with haemolytic and cytolytic activities (Grangemard et al., 1997). Genetic modifications of the surfactin biosynthesis machinery resulted in the production of a lipohexapeptide with reduced toxicity against erythrocytes and an increased inhibition of bacterial cells, including those of B. licheniformis (Symmank et al., 2002). Molecular manipulations in surfactin structure offer a possibility of constructing new derivatives with potent surfactant and antimicrobial activity. In the field of biological control of plant diseases, rhizobacteria capable of producing such compounds are a very tempting alternative for syntetic pesticides, being easily biodegradable and safe, with no adverse effects on humans.

\section{ANTIBIOTICS - 'PROPER TIME AND COMBINATION'}

During the bacterial growth surfactins are the first to be synthesized (Cosby et al., 1998). Secondary metabolites, such as iturin A, are generally produced after the logarithmic growth phase, when the cells have exhausted one or more essential nutrients (Mizumoto et al., 2006). In the moment of transition between exponential and stationary growth, maximal production of mycosubtilin was observed (Toure et al., 2004). Apparently, at every step of bacterial growth antimicrobial activities are present. It is another argument explaining the great potential of bacteria possessing a wide range of produced antibiotics. Simultaneously, the excretion of surfactin and other lipopeptides is often observed in Bacillus spp. (Souto et al., 2004). Mixtures of surfactin and iturin produced by B. subtilis RB14 and B. amyloliquefaciens BNM122 increase the antifungal activity, since the former compound is able to form mixed micelles with iturin and thereby improve its activity (Thimon et al., 1992). B. subtilis GA1 is a producer of a wide variety of lipopeptides: iturin A, surfactins and fengycins with various lengths of the fatty acid chains from C14 to C18 (Toure et al., 2004). Another example is B. subtilis ATCC6633 with the ability to produce subtilin, subtilosin, and lipopeptides surfactin and mycosubtilin (Leclere et al., 2005). In addition, studies of the kinetics of production of those compounds suggest that it might be some kind of a synergistic effect in eliminating the competitors in the habitat. Increasing the diversity of antibiotics excreted by the organism to the soil might result in an increase of the range of action on different phytopathogens. Thimon et al. (1992) demonstrated that co-production of surfactin, which has a strong surfactant activity, with iturin, enhances antifungal properties of iturin A. Stein (2005) speculates that the frequent occurrence of $B$. subtilis among other Bacilli in the natural environment might be due to the selective advantage conferred by the produced metabolites.

No single Bacillus strain produces all of the antibiotics depicted above. However, simultaneous production of some of these compounds by specific strains is often observed. A list of the antibacterial and antifungal compounds produced by different B. subtilis and B. amyloliquefaciens strains, including their mechanism of action and targets, is displayed in Table 1.

\section{CAN PLANTS BENEFIT FROM MULTICELLULAR COOPERATION OF BACTERIA?}

The role played in the soil by B. subtilis is poorly understood. This is mainly due to the fact that we got used to examining the activities and life cycle of microbes in laboratory conditions, which are far from the natural environment. Since soil is a mixture of sand, silt and a variety of mineral compounds, it is hard to put an equals sign between a natural niche and a laboratory medium. Unfortunately, the social behaviour of microorganisms in natural environment is poorly understood. The phenomena such as a quorum sensing, biofilm formation as well as detaching, different mode of movement seem to be elaborated processes a highly connected with each other. They are also believed to play a crucial role in the adaptative strategies in microbial life (Shapiro, 1998).

So far, most of the studies on B. subtilis have focused primarily on the 168 strain (Marburg), cultivated in the laboratory conditions for several decades, which led to the accumulation of numerous mutations. First of all, those DNA changes of domesticated strain are responsible for swarming phenotype different from natural isolates (Kearns et al., 2004). What is more, the 168 Marburg is unable to produce lipopeptides, e.g., surfactin, fengycin and iturin. A frameshift mutation in the sfp gene coding for $4^{\prime}$-phosphopantetheine transferase, which is 
responsible for conversion of nascent antibiotic synthetases to their active holoforms, causes this defect (Nakano et al., 1992). Interestingly, introduction of a native sfp gene into $B$. subtilis 168 provoked surfactin and fengycin production (Tsuge et al., 1999). In the case of iturins, on the basis of whole-genome sequence data, B. subtilis strain 168 does not have the iturin group operon (Kunst et al., 1997). Analogically, Tsuge et al. (2005) demonstrated that conversion of the non-iturin A producer (B. subtilis 168) into an iturin producer requires the introduction of both the region containing the iturin A operon and the sfp gene. The genetic changes described above explain, at least partly, the different social behaviour of strain 168 in comparison to wild-type isolates of B. subtilis (Kearns \& Losick, 2003; Julkowska et al., 2005; Calvio et al., 2005; Leclere et al., 2006).

\section{'STEP BY STEP' - TRANSLOCATION OF PGPR}

When analyzed within the context of biocontrol, the translocation processes of PGPR bacteria seems to warrant more attention. Motility on surfaces is an important mechanism for bacterial colonization of new environments. Furthermore, the ability to move in a directional manner may confer distinct advantages upon host-adapted prokaryotes.

There are few investigations reporting that motility is essential for the initial steps of development of microbial biofilms, which are often basic condition of beneficial effects of PGPR (Kinsinger et al., 2003). Motility definitely helps to establish a stable relationship with the plant surface, as it favoures rapid and effective colonization. Avoidance of antimicrobial compounds, produced either by the host or by competitors inhabiting the same niche, also seems to be important for maintaining this contact. Better access to nutrients and translocation to favourable colonization sites are an additional advantage of the active movement of bacteria within the rhizosphere. Rapid colonization on the host surface means winning the competition with antagonists (Shapiro, 1998; Kinsinger et al., 2003). Taking into account that phytopathogenic fungi as well as other soil-dwelling competitors of PGPR bacteria are highly motile organisms, it is easy to realize how important is motility for survival in the environment. From a more global point of view, it becomes clearly visible how motility can influence host colonization, which is a crucial step in biocontrol.

Since swimming, perceived as a basic mode of movement, is connected with a single cell, which reacts and respond to particular chemical signals in the environment, swarming is a multicellular, coordinated movement, generated by successive waves of moving cells on a solid surface. Rapidly spreading dendritic structures are typical for this flagellum-driven motility (Julkowska et al., 2005). In contrast to swimming, where chemotaxis is the basic response of the cell to environmental stimuli, it is unknown if the chemotaxis sensory system plays a role in swarming, too (Calvio et al., 2005). However, swarming is thought to be dependent on cell density signals. Furthermore, a role of powerful surfactants in switching from swimming to swarming motility has also been established. This is not surprising, since regulation via a quorumsensing system is strictly connected with production of the mentioned lipopeptides (Connelly et al., 2004; Morikawa, 2006). A swarming cell undergoing morphological changes becomes elongated and hyperflagellated in comparison to planktonic swimmers. This morphological differentiation is reversible, since swarmers can revert into shorter and less flagellated swimming cells under certain conditions (Leclere et al., 2006). In both cases, a functional movement apparatus is required. However, genes governing flagella synthesis and assembly as well as the environmental signal transduction leading to flagella formation are poorly understood. Recently, it was concluded that protein SwrAA has a pivotal role in regulating the degree of cell flagellation, whereas SwrAB seems to be essential for differentiation in response to bacterial contact with a solid surface. Because of the presence of conserved interaction module PDZ, the SwrAB may contribute to the processing of SwrAA protein (Jeleń et al., 2003; Calvio et al., 2006). Additionally, efp and swrC genes were found to be crucial for massive migration through solid, but not in liquid media. The protein encoded by $s w r C$ is required for resistance to the antimicrobial activity of surfactin as SwrC prevents its accumulation in the cell (Kearns et al., 2004). As it was underlined above, laboratory strains harbouring frameshift mutations in some genes $(s f p, s w r A A)$ displayed a swarming phenotype different from the normal one (Kearns et al., 2004). It was discovered, partly in our laboratory, that wild-type strain 3610, in contrast to the domesticated strain 168, was able to swarm on a synthetic, fully defined medium. In the case of 3610 strain, incredible patterns generated by successive waves of moving cells could be obtained on plates (Fig. 1). The domesticated strain 168, which does not produce surfactin, swarms only on Luria-Bertani (LB) agar, displaying less swarming activity and reduction in speed of colonization (Julkowska et al., 2004; 2005). An experiment consisting in introduction of $s p^{+}$allele into the chromosome showed that this biosurfactant is needed for the swarming behaviour because many features observed for 3610 on LB medium were restored in the transgenic 168 . Lowering the surface tension is one of the many 
Table 1. Active substances produced by Bacillus strains and their mechanism of action.

\begin{tabular}{|c|c|c|}
\hline B. subtilis strain & $\begin{array}{l}\text { Mechanisms of antagonistic interactions } \\
\text { - basic information }\end{array}$ & Antagonist (plant host) \\
\hline \begin{tabular}{|l|} 
1. CE1 \\
(Cavaglieri et al., 2005)
\end{tabular} & $\begin{array}{l}\text { inhibition of Fusarium verticillioides growth } \\
\text { and fumonisin } B_{1} \text { accumulation in vitro }\end{array}$ & $\begin{array}{l}\text { Fusarium verticillioides (maize root patho- } \\
\text { gen) }\end{array}$ \\
\hline $\begin{array}{l}\text { 2. } \text { B }_{1} \\
\text { (Okigbo, 2005) }\end{array}$ & $\begin{array}{l}\text { inhibition of mycelia of primary rot produc- } \\
\text { ing fungus in vitro; total inhibition of rot } \\
(99-100 \%) \text { in postharvest storage }\end{array}$ & $\begin{array}{l}\text { Penicillium oxalicum, Aspergillus niger, } \\
\text { Fusarium solani (rot of yam in storage } \\
\text { barns) }\end{array}$ \\
\hline $\begin{array}{l}\text { 3. BBG100 } \\
\text { (Leclere et al., 2005) }\end{array}$ & $\begin{array}{l}\text { increase in germination rate of seeds tomato; } \\
\text { mycosubtilin and surfactin production }\end{array}$ & $\begin{array}{l}\text { Botrytis cinerea, Fusarium oxysporum, } P . \\
\text { aphanidermatum, Pichia pastoris, S. cerevisiae }\end{array}$ \\
\hline $\begin{array}{l}\text { 4. ZJY-116 } \\
\text { (Zhang et al., 2005) }\end{array}$ & $\begin{array}{l}\text { effective suppression of Fusarium head blight } \\
\text { (in field experiments); competition for space } \\
\text { and resources; releasing secondary metaboli- } \\
\text { tes that inhibit growth of F. graminearum }\end{array}$ & $\begin{array}{l}\text { Fusarium graminearum (FHB- Fusarium } \\
\text { head blight of wheat and barley) }\end{array}$ \\
\hline $\begin{array}{l}\text { 5. IFS-01 } \\
\text { (Földes et al., 2000) }\end{array}$ & $\begin{array}{l}\text { production of either a broad spectrum of } \\
\text { antimicrobial agents or several compounds } \\
\text { with different activities }\end{array}$ & $\begin{array}{l}\text { filamentous fungi (Aspergillus wentii, Peni- } \\
\text { cillium chrysogenum) yeasts (Yarrowia lipo- } \\
\text { lytica, Rhodotorula mucilaginosa) and } \\
\text { Gram-positive bacteria (Listeria monocyto- } \\
\text { genes, Staphylococcus aureus) }\end{array}$ \\
\hline $\begin{array}{l}\text { 6. B2 } \\
\text { (Marten et al., 2000) } \\
\text { Phytovit - commercially available } \\
\text { from Prophyta GmbH } \\
\end{array}$ & & $\begin{array}{l}\text { pathogenic fungi: Pythium ultimum, Rhi- } \\
\text { zoctonia solani }\end{array}$ \\
\hline $\begin{array}{l}\text { 7. QST } 713 \\
\text { www.agraquest.com/products }\end{array}$ & $\begin{array}{l}\text { Serenade }^{\circledR}-\text { produces over } 30 \text { different } \\
\text { lipopeptides that work synergistically to de- } \\
\text { stroy disease-causing pathogens; } \underline{\text { Rhapsody }}{ }^{\mathbb{B}} \\
\text { controls a wide array of foliar and soil dise- } \\
\text { ases on turf and ornamentals }\end{array}$ & \\
\hline $\begin{array}{l}\text { 8. A30 (Chen et al., 1997) } \\
\text { A014 (Liu et al., 1991) } \\
\text { S0113 (Lin et al., 2001) } \\
\end{array}$ & $\begin{array}{l}\text { production of anti-Xoo peptide acting thro- } \\
\text { ugh different molecular mechanisms }\end{array}$ & $\begin{array}{l}\text { Gram-negative bacteria, vascular pa- } \\
\text { thogen causing bacterial blight of rice } \\
\text { - Xanthomonas oryzae pv. oryzae (Xoo) }\end{array}$ \\
\hline $\begin{array}{l}\text { 9. } 6051 \\
\text { (Bais et al., 2004) }\end{array}$ & $\begin{array}{l}\text { formation of protective and antimicrobial } \\
\text { biofilms on root surface of Arabidopsis; } \\
\text { secretion of lipopeptide antibiotic surfactin }\end{array}$ & $\begin{array}{l}\text { Pseudomonas syringae pv. tomato DC3000 } \\
\text { (potent leaf pathogen in Arabidopsis) }\end{array}$ \\
\hline $\begin{array}{l}\text { 10. M4 } \\
\text { (Ongena et al., 2004; 2005a; 2005b) }\end{array}$ & $\begin{array}{l}\text { ISR (induced systemic resistance) - activates } \\
\text { host defense system; fengycin production } \\
\text { which induced synthesis of plant phenolics }\end{array}$ & $\begin{array}{l}\text { Colletotrichum lagenarium (cucumber } \\
- \text { Cucumis sativus disease), } \\
\text { Pythium aphanidermatum (damping-off of } \\
\text { tomato), Botrytis cinerea (bean diseases) }\end{array}$ \\
\hline $\begin{array}{l}\text { 11. GA1 } \\
\text { (Toure et al., 2004) }\end{array}$ & $\begin{array}{l}\text { grey mould disease reduction (inhibition of } \\
\text { mycelial growth) - production of antifungal } \\
\text { lipopeptides: iturins, fengycins type A; B, } \\
\text { surfactin families }\end{array}$ & $\begin{array}{l}\text { Botrytis cinerea (grey mould disease of } \\
\text { apples) }\end{array}$ \\
\hline $\begin{array}{l}\text { 12. L-forms of B. subtilis } \\
\text { (Walker et al., 2002) }\end{array}$ & $\begin{array}{l}\text { symbiotic relationship with Chinese cabbage; } \\
\text { production of antibiotic in pure culture acti- } \\
\text { ve against } B \text {. cinerea in vitro }\end{array}$ & $\begin{array}{l}\text { Botrytis cinerea (grey mould disease of } \\
\text { Chinese cabbage) }\end{array}$ \\
\hline $\begin{array}{l}\text { 13. B2; B5; B7; B8 } \\
\text { (Li et al., 2005) }\end{array}$ & $\begin{array}{l}\text { strong nematicidal activity - killing second } \\
\text { stage larvae; production of active factors } \\
\text { (heat stability, resistance to extreme } \mathrm{pH} \text { val- } \\
\text { ues - putative antibiotic character) }\end{array}$ & $\begin{array}{l}\text { Rhizoctonia solani SX-6, Pythium aphanider- } \\
\text { matum ZJP-1, Fusarium oxysporum f.sp. } \\
\text { cucumerinum ZJE-2 (root-knot nematode } \\
\text { and soil-borne fungi); } \\
\text { larvae Meloidogyne javanica } \\
\end{array}$ \\
\hline \begin{tabular}{|l|} 
14. RC8; RC9; RC11 \\
(Cavaglieri et al., 2004) \\
\end{tabular} & $\begin{array}{l}\text { inhibition of fumonisin } \mathrm{B}_{1} \text { production (myco- } \\
\text { toxin); strong fungal growth inhibition }\end{array}$ & Fusarium verticillioides \\
\hline $\begin{array}{l}\text { 15. RRC101 } \\
\text { (Bacon et al., 2001) }\end{array}$ & $\begin{array}{l}\text { reduction of mycotoxin accumulation; } \\
\text { 'ecological homolog' of } F \text {. moniliforme-com- } \\
\text { petition }\end{array}$ & $\begin{array}{l}\text { Fusarium moniliforme Sheldon (facultative } \\
\text { fungal endophyte of Zea mays) }\end{array}$ \\
\hline $\begin{array}{l}\text { 16. AF } 1 \\
\text { (Manjula \& Podile, 2001; } \\
\text { Manjula et al., 2004) }\end{array}$ & $\begin{array}{l}\text { significant root-colonizing ability and survi- } \\
\text { val when introduced into rhizosphere; redu- } \\
\text { ced incidence of wilt in pigeon pea; potential } \\
\text { biocontrol agent of Aspergillus niger through } \\
\text { chitynolysis } \\
\text { ( } \beta-1,4-N \text {-acetyloglucosaminidase production } \\
- \text { chitinase) and induction of host defense } \\
\text { response }\end{array}$ & $\begin{array}{l}\text { Aspergillus niger (crown rot of groundnut, } \\
\text { soft rot in lemons); Puccinia arachidis (rust } \\
\text { in groundnut); F. udum (wilt of pigeon } \\
\text { pea) }\end{array}$ \\
\hline
\end{tabular}




\begin{tabular}{|c|c|c|}
\hline $\begin{array}{l}\text { 17. JA; JA026 } \\
\text { (Liu et al., 2005) }\end{array}$ & $\begin{array}{l}\text { antifugal lipopeptides }(1400-1500 \mathrm{Da}) \text { from } \\
\text { fengycin family }\end{array}$ & $\begin{array}{l}\text { Gibberella zeae (anamorph of Fusarium gra- } \\
\text { minearum) - Fusarium head blight (FHB) } \\
\text { in wheat, barley, ear rot in corn }\end{array}$ \\
\hline $\begin{array}{l}\text { 18. BS21; BS22; BS23 } \\
\text { (Adebanjo \& Bankole, 2004) }\end{array}$ & $\begin{array}{l}\text { reduction of seeding infection by anthrac- } \\
\text { nose; severity of anthracnose disease; reduc- } \\
\text { tion of pathogen inoculums and displace- } \\
\text { ment of pathogen }\end{array}$ & $\begin{array}{l}\text { Colletotrichum lindemuthianum (anthrac- } \\
\text { nose disease of cowpea) }\end{array}$ \\
\hline $\begin{array}{l}\text { 19. PY79 } \\
\text { (Stöver \& Driks, 1999) }\end{array}$ & $\begin{array}{l}\text { TasA-secreted protein with broad spec- } \\
\text { trum antibacterial activity and inhibition of } \\
\text { growth of competitor bacteria in nature }\end{array}$ & $\begin{array}{l}\text { plant pathogens: Agrobacterium tumefaciens } \\
\text { GV3101, Pseudomonas sp., Klebsiella sp., } \\
\text { Erwinia sp.; } \\
\text { animal pathogens: Enterococcus faecalis, } \\
\text { Escherichia coli, Staphylococcus epidermis; } \\
\text { clinical isolates including human patho- } \\
\text { gens: Enterobacter sp., Klebsiella pneumo- } \\
\text { niae, Pseudomonas aeruginosa }\end{array}$ \\
\hline $\begin{array}{l}\text { 20. Natural isolate } \\
\text { (Kawulka et al., 2004; Thennarasu } \\
\text { et al., 2005) }\end{array}$ & subtilosin A - bactericidal activity & $\begin{array}{l}\text { diverse range of Gram-positive and } \\
\text { Gram-negative bacteria }\end{array}$ \\
\hline $\begin{array}{l}\text { 21. UMAF6614; UMAF6619; } \\
\text { UMAF6639; UMAF8561 } \\
\text { (Romero et al., 2007) }\end{array}$ & $\begin{array}{l}\text { excreted antibiotics (surfactin, fengycin, itu- } \\
\text { rin A, bacillomycin) major factors involved } \\
\text { in biocontrol activity }\end{array}$ & $\begin{array}{l}\text { Podosphaera fusca (cucurbit powdery mil- } \\
\text { dew) }\end{array}$ \\
\hline $\begin{array}{l}\text { 22. BS } 107 \\
\text { (Sharga \& Lyon, 1998) }\end{array}$ & antibiotic production & $\begin{array}{l}\text { Erwinia carotovora subsp. atroseptica and } \\
\text { Erwinia carotovora subsp. carotovora (causal } \\
\text { agents of potato blackleg and tuber soft } \\
\text { rot) }\end{array}$ \\
\hline $\begin{array}{l}\text { 23. C1 } \\
\text { (Singh \& Cameotra, 2004) }\end{array}$ & biosurfactant - lipopeptide N1 & $\begin{array}{l}\text { Mycobacterium smegmatis, Staphylococcus } \\
\text { aureus }\end{array}$ \\
\hline $\begin{array}{l}\text { 24. GB03 } \\
\text { (Raupach \& Kloepper, 1998) }\end{array}$ & $\begin{array}{l}\text { use of GB03 in combination with two other } \\
\text { PGPR strains caused intensive plant growth } \\
\text { promotion; disease reduction (better plant } \\
\text { colonization, large number of pathogen-sup- } \\
\text { pressive mechanisms) }\end{array}$ & $\begin{array}{l}\text { Colletotrichum orbiculare (anthracnose), } \\
\text { Pseudomonas syringae pv. lachrymans (an- } \\
\text { gular leaf spot), Erwinia tracheiphila (cu- } \\
\text { curbit wilt disease) }\end{array}$ \\
\hline $\begin{array}{l}\text { 25. RB14-CS } \\
\text { (Mizumoto et al., 2006) }\end{array}$ & lipopeptide production: iturin A & $\begin{array}{l}\text { Rhizoctonia solani (causal agent of damp- } \\
\text { ing-off of tomato) }\end{array}$ \\
\hline $\begin{array}{l}\text { 26. LEV-006 } \\
\text { (Hou et al., 2006) }\end{array}$ & $\begin{array}{l}\text { strong, stable antifungal activity; production } \\
\text { of fengycins A nad B }\end{array}$ & $\begin{array}{l}\text { Rhizoctonia solani (seedling blight and root } \\
\text { rot), Sclerotinia sclerotiorum (stem rot), Al- } \\
\text { ternaria brassicae (black spot), Leptosphaeria } \\
\text { maculans (black leg) }\end{array}$ \\
\hline $\begin{array}{l}\text { 27. ATCC } 21332 \\
\text { (Symmank et al., 2002) }\end{array}$ & $\begin{array}{l}\text { novel lipohexapeptide after engineering of } B \text {. } \\
\text { subtilis surfactin synthetase resulted in redu- } \\
\text { ced toxicity against erythrocytes and enhan- } \\
\text { ced lysis of B. licheniformis cells }\end{array}$ & B. licheniformis \\
\hline \multicolumn{3}{|l|}{ B. amyloliquefaciens strain } \\
\hline $\begin{array}{l}\text { 28. MET0908 } \\
\text { (Kim \& Chung, 2004) }\end{array}$ & $\begin{array}{l}\text { B-1,3-glucanases - decomposition of fungal } \\
\text { hyphal walls }\end{array}$ & $\begin{array}{l}\text { Colletotrichum lagenarium (watermelon } \\
\text { anthracnose) }\end{array}$ \\
\hline $\begin{array}{l}\text { 29. RC-2 } \\
\text { (Hiradate et al., 2002) }\end{array}$ & $\begin{array}{l}\text { lipopeptide production: } \\
\text { iturins A-2-A-8 }\end{array}$ & $\begin{array}{l}\text { Colletotrichum dematium (mulberry an- } \\
\text { thracnose) }\end{array}$ \\
\hline $\begin{array}{l}\text { 30. B94 } \\
\text { (Yu et al., 2002) }\end{array}$ & $\begin{array}{l}\text { antibiotic production (iturin A) involved in } \\
\text { disease-suppression }\end{array}$ & $\begin{array}{l}\text { Rhizoctonia solani (pre- and post-emer- } \\
\text { gence damping-off of soybean) }\end{array}$ \\
\hline $\begin{array}{l}\text { 31. FZB45 } \\
\text { (Idriss et al., 2002) }\end{array}$ & $\begin{array}{l}\text { stimulated growth of maize seedlings under } \\
\text { phosphate limitation in the presence of ex- } \\
\text { tracellular phytate - production of phytases }\end{array}$ & Zea mays \\
\hline $\begin{array}{l}\text { 32. BNM } 122 \\
\text { (Souto et al., 2004) }\end{array}$ & $\begin{array}{l}\text { co-production of surfactin and iturin-like } \\
\text { antibiotics against various plant pathogenic } \\
\text { fungi }\end{array}$ & $\begin{array}{l}\text { Fusarium oxysporum f. sp lycopersici, Fu- } \\
\text { sarium solani, Rhizoctonia solani, Sclerotinia } \\
\text { sclerotiorum }\end{array}$ \\
\hline
\end{tabular}

activities of surfactin, which is secreted at the edges of a growing colony. The production of extracellular lipopeptide was proved to be stimulated by $\mathrm{K}^{+}$ions, but the precise mechanism remains unknown (Kinsinger et al., 2003). The important find- ing of this investigation was also that apart form structural changes of the cell and specialization of particular groups of swarmers the process can also be characterized as time-dependent. Analyzing the behaviour of a swarmers' community indicated 


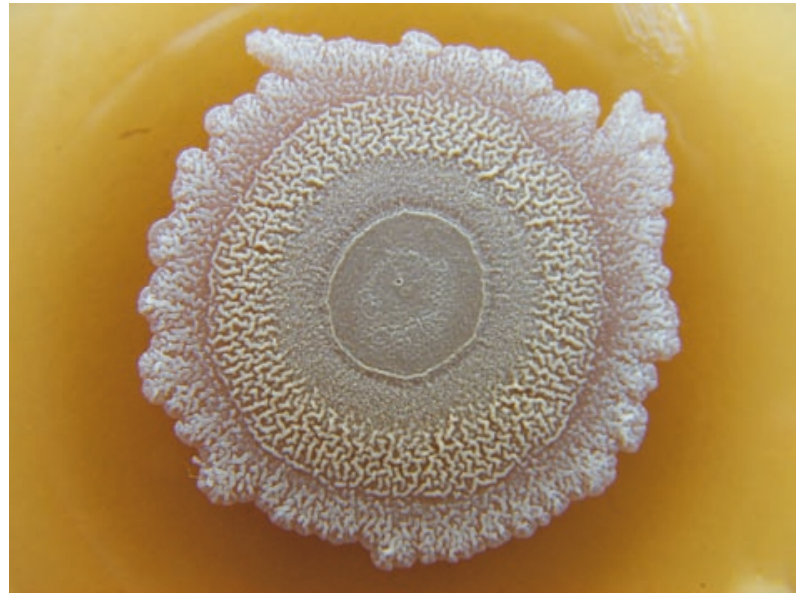

Figure 1. Swarming pattern generated by B. subtilis 3610.

that two waves of migration can be distinguished. The first swarm is detected at $11 \mathrm{~h}$ from inoculation, whereas the second one appears at 18-22 $\mathrm{h}$ (Julkowska et al., 2005).

During swarming, the number of interactions between factors, often unidentified, causes the nature of this process to be extremely elaborated. One of them is the production of surfactin, a powerful compound serving a wide variety of different functions in bacterial vegetation (Mulligan, 2005). It has been shown that lipopeptide production can be essential for motility also in other groups of bacteria. The poorly known surface translocation phenomenon of Pseudomonas sp. DSS73, a strain isolated from the rhizoplane of sugar beet seedlings, depends on the presence of amphisin (Andersen et al., 2003). Production of cyclic lipopeptides in combination with the presence of flagella allows the growing colony of bacteria to translocate effectively through the plant surfaces, thus colonizing it. A synergistic effect of the mentioned mode of movement and production of a wide range of toxic substances seems to inhibit growth of pathogen fungi such as Pythium ultimum and $R$. solani. Amphisin as well as tensin and viscosin belong to the group of bifunctional substances. They not only have an antifungal potential, but they can also influence surface properties. The specific morphology of swarmers combined with the production of biosurfactants and the process of water removal from the surface reduces friction forces leading to effective expansion of the surface (Matsuyama et al., 1992; Bees et al., 2000). It is worth pointing out that a close correlation between the production of the dual-functioning compounds and translocation through the surface of low-percentage agar was proved also in the case of other Gram-negative bacteria such as Serratia spp. and Pseudomonas spp. (Matsuyama et al., 1992; Nielsen et al., 2002).

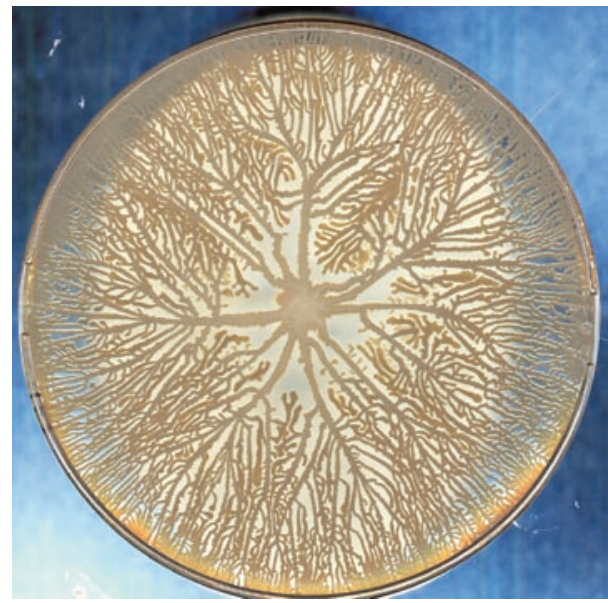

Figure 2. Biofilm formed on solid media by B. subtilis 3610 .

\section{EXTRACELLULAR PROTEOLYTIC ACTIVITY PLAYS A CENTRAL ROLE IN MULTICELLULAR BEHAVIOUR}

Another common feature of multicellular processes is participation of extracellular proteases. An obvious role of those enzymes is degradation and acquisition of nutritional factors from the surrounding environment. However, on the basis of some recent reports it can be predicted that those extracellular proteases could also act either on the bacterial cell proteins itself or on proteins secreted by the cell, which means that their role need not be limited to nutritional only (Connelly et al., 2004). The B. subtilis PRY strain presents very robust swarming behaviour, which is a result of high serine protease production (Park et al., 2006). Those results are in agreement with the results published at the same time by the Murudkar's group (Murudkar et al., 2006). They showed that Epr, a minor extracellular serine protease, plays a significant role in swarming motility of $B$. subtilis 168 . One of the functions of those extracellular proteases is cleavage of signal peptides which participate in quorum-sensing communication, which could be easily linked to swarming. It was also suggested that they modify the cell surface and release some peptides involved in swarming by digesting cell surface proteins. However, the proteolytic activity of Epr was not required for swarming (Murudkar et al., 2006). Considering the extracellular proteolytic activity, contribution of mainly subtilisin (AprE) and neutral metalloprotease $\mathrm{E}(\mathrm{NprE})$ is predominant (Connelly et al., 2004). Eight main extracellular proteases reach the highest level of expression at the end of the logarithmic phase of growth. In spite of the fact that their expression is tightly controlled, they do not seem to be essential for either sporulation or bacterial growth. Several studies 
have taken into account the role of those enzymes in swarming. It was shown that sigF, nprE, aprE or amyE have only very limited function in this process. However, it is worth pointing out that a strain harbouring mutations in all listed genes displayed a completely non-swarming phenotype (Connelly et al., 2004). On the basis of those results, it can be concluded that the complexity of motile behaviour and its interaction as well as influence on other multicellular processes like biofilm formation needs to be established in more detail.

\section{'BIOFILMS - EASY WAY TO RECOVER'}

Biofilms are viewed as highly structured multispecies communities, a prevalent form of existence of microorganisms in every ecosystem (Fig. 2). The process of surface adhesion and biofilm development is an effective survival strategy employed by virtually all bacteria and refined over millions of years (Shapiro, 1998). Among other bacteria, B. subtilis is also believed to form a robust biofilm on biotic as well as abiotic surfaces. However, in laboratory conditions the most common form of this structure are pellicles, which are robust floating biofilms formed at the air-liquid interface. At the point of entering the stationary phase of growth motile cells of $B$. subtilis migrate to the air-medium interface. Once they reach the surface, cells start to differentiate into aligned chains of attached cells that eventually produce aerial structures or fruiting bodies serving as preferential sites for sporulation (Branda et al., 2001). When analyzed within the context of highly structured, surface-associated communities (biofilms), active movement was discovered to have a crucial meaning for the initial steps of biofilm development (Mireles et al., 2001). As it was pointed out, biofilm and swarming share some features, such as a quorum-sensing communication, active movement, as well as morphological changes of the cells. What is more, in both cases an increase in slime production is observed (Toguchi et al., 2000). Another evidence for a direct link between those phenomena is the fact that certain factors which reduce swarming motility also inhibit biofilm formation. (5Z)-4-Bromo5-(bromomethylene)-3-butyl-2(5H)-furanone of the marine alga Delisea pulchra has been shown to be an antimicrobial compound, as it can affect multicellular activities of $B$. subtilis. Probably due to structure similarity between furanone and one of the quorum sensing signals, AI-2, a significant defect of swarming motility as well as biofilm formation could be observed. The presence of the furanone caused reduction in the swarming speed in a dose-dependent manner and at a concentration of $40 \mu \mathrm{g} \mathrm{ml}^{-1}$ led to a $25 \%$ decrease in biofilm thickness (Ren et al., 2002).
A connection between different mode of movement and biofilm formation was established in the case of B. subtilis (Branda et al., 2001). For instance, a protease- and surfactin-deficient strain, which displayed a significant defect in swarming, showed at the same time reduction in biofilm formation: the mutant formed very thin and flat pellicles in comparison to wild type. This is another step in confirming the hypothesis that biofilm formation and swarming can have overlapping control mechanisms (Connelly et al., 2004). A convincing support for this hypothesis is delivered also by authors examining the function of the waaE gene which participates in the biosynthesis of the inner-core LPS in Gram-negative bacteria (Izquierdo et al., 2002). Lack of the waaE gene was found to affect both swarming motility and biofilm development in Serratia marcescens and P. mirabilis. This observation can explain, at least partially, the fact that the waaE mutant displayed a drastic reduction in the ability to infect and colonize the urinary tract of rat (Izquierdo et al., 2002). As a collective bacterial process, swarming is not only associated with biofilm formation, but also with expression of virulence by pathogenic bacteria. Generally, it should be underlined that both processes are strongly related to diseases.

In natural environments bacteria establish symbiotic or pathogenic biofilms on plant or animal body surfaces. Effective colonization of plant roots by PGPR plays an important role in plant growth promotion. Plant roots secrete a vast array of compounds into the rhizosphere, which are determinative factors promoting bacterial colonization on the plant root. There is a number of investigations reporting a relationship between $B$. subtilis and the rhizoplane as well as rhizosphere of tea bushes (Pandey et al., 1997). B. subtilis 430A was also isolated from the Vernonia herbacea (Vell Rusby) rhizosphere, where it produces an exocellular inulinase (Vullo et al., 1991). Results obtained recently indicate that $B$. subtilis is a prevalent inhabitant of the rhizosphere of many plant species due to the fact that it forms robust biofilms on the root surface (Ongena et al., 2005a). The Gram-negative soil bacterium Pseudomonas fluorescens was also found to form biofilms on the root surface of particular species of plant. Unfortunately, a relation between biofilm formation and plant protection ability has not been established (Bianciotto et al., 2001). It is postulated that this kind of relationship can be beneficial to both partners. On the root surface, protection from environmental dangers and cooperation in order to gain nutrient are favoured by this mode of development (Danhorn \& Fuqua, 2007). A good example of this kind of relationship is $B$. subtilis 6051, a natural inhabitant of soil, which was found to form robust biofilms on Arabidopsis roots. Mortality of plants caused by Pseudomonas syringae 
pv tomato DC3000 was reduced from $85 \%$ to $10 \%$ due to co-cultivation with 6051 strain both in vitro and in a sterile soil. Furthermore, it was proved that the presence of surfactin effectively prevents root colonization by planktonic cells of a pathogen. Bais et al. (2004) showed that B. subtilis strain defective in surfactin production (strain M4) is not able to colonize roots plant effectively and the biofilm formed is much thinner in comparison to wild type. Furthermore, this kind of mutation makes the analyzed M4 strain ineffective against $P$. syringae.

It has also been reported that surfactin inhibits biofilm development by Salmonella enterica as well as Escherichia coli and Pseudomonas mirabilis (Mireles et al., 2001).

\section{ANOTHER PHENOMENON POTENTIALLY USEFUL IN BIOCONTROL}

It was proved that colonization of cucumber and tomato roots by B. subtilis M4 could influence expression of the plant's genes. This kind of action, known as ISR (induced systemic resistance), is believed to be responsible for the reduction of disease incidence caused by Colletotrichum lagenarium and P. aphanidermatum (Ongena et al., 2004). The experiments performed revealed that B. subtilis M4 is effective against pathogenic fungi due to induction of plant host resistance. Recently, the ISR phenomenon and the bacterium causing it have received a great deal of interest. Although this is a rather new phenomenon and still a lot needs to be discovered in this field, some information concerning the molecular mechanism of the process is available. For instance, an increase in lipoxygenase activity in tomato cells after plant treatment with a $B$. subtilis strain overexpressing both surfactin and fengycins was observed (Ongena et al., 2007). Together with fengycin, surfactin was found to be the signal recognized by the plants which in response initiated defense mechanisms. What is interesting, an induction of plant resistance has been shown, because treatment with either vegetative cells or endospores of $B$. subtilis M4 leads to a significant reduction in anthracnose, which is a devastative disease of cucumber (Ongena et al., 2005a). Similarly, Methylobacterium sp. PPFM-Ah isolated from groundnut leaves was found to increase the level of enzymatic substances such as chitinases and $\beta-1,3$-glucanases in the plant, which showed a synergistic antifungal activity, and of enzymes participating in cell-wall lignification (Madhaiyan et al., 2006). Defense-gene activation in pea (Pisum satioum), normally susceptible to pathogen infection, was confirmed for the endophytic bacterium B. pumilus strain SE34. The host defence reactions included strengthening of the epidermal and cortical cells, which contain large amounts of callose. These changes associated with the cell wall allowed the plant to defend effectively against the pea rootrotting fungus Fusarium oxysporum f. sp. Pisi (Benhamou et al., 1996). Furthermore, ISR is phenotypically similar to systemic acquired resistance (SAR), which is activated either by the first pathogenic infection or treatment with some chemical substances. However, it is believed that the signal transduction as well as the molecular basis of those processes is different. So far, ISR was associated mainly with Gram-negative bacteria belonging to the genera Serratia and Pseudomonas (van Loon et al., 1998). This kind of microorganism-plant interactions was reported also for B. pumilus and B. amyloliquefaciens (Benhamou et al., 1996).

Bacteria belonging to the PGPR group can stimulate growth of many plants due to facilitated assimilation of additional phosphorus from the surrounding soil, lack of which is an important limiting growth factor (Kerovuo et al., 1998). Phosphorus in soil, apart from polyphosphates, is present as phytate, a salt form of phytic acid (myo-inositol hexakisphosphate), which accounts for $20-50 \%$ of total soil organic phosphorus. In general, phosphomonoesterases, unlike phosphatases, are able to hydrolyse phytate (Idriss et al., 2002). Few studies have taken into account plant phytases and it was found that these enzymes exhibited only a very low level of activity in organs, including roots. It is also suggested that plants can not acquire phosphorus directly from soil phytate. Several attempts of cloning and using plant genes encoding phytases have failed (Maugenest et al., 1999). In contrast, the desired effect was obtained when purified protein with phytase activity from a fungus - Aspergillus sp. was added to the root system (Richardson et al., 2001). It is also known that phytases are produced and secreted by a wide range of both Gram-negative and Grampositive bacteria, including $B$. subtilis (Kerovuo et al., 1998), B. amyloliquefaciens DS11 (Kim et al., 1998), Klebsiella terrigena (Greiner et al., 1997), Pseudomonas spp. (Richardson \& Hadobas, 1997). In this context, it is tempting to speculate that bacteria which make phytate available for the plant under phosphate-starvation condition can contribute to plant growth. So far, there are few reports confirming this idea. Idriss et al. (2002) showed that phytases secreted by some strains from the Bacillus genus promote growth of maize seedlings under limiting soil phosphorus conditions. To date, only few phytases excreted by $B$. subtilis strains have been isolated and characterized. For instance, strain VTT E-68013 produces a novel enzyme, which does not contain the highly conserved RHGXRXP sequence typical for the active site of known phytases. Phytase PhyC is produced when inorganic phosphate is a limiting factor (Kero- 
vuo et al., 1998). Having maximal phytase activity at $\mathrm{pH} 7$ and $55^{\circ} \mathrm{C}$, PhyC together with PhyA isolated from strain 168 are candidates for transgenic studies. To our knowledge, most known phytases are active only in the acidic $\mathrm{pH}$, moreover, they exhibit very little enzymatic activity at neutral pH (Wyss et al., 1999). Therefore the Bacillus phytases offer advantages which seem to be crucial for future application. PhyA and PhyL exhibited broad temperature and $\mathrm{pH}$ optima and showed high thermostability. Other properties, like high specifity, gave credence to an idea of creating a new biochemical pathway in transgenic plants that would mobilize inorganic phosphate from phytate (Tye et al., 2002). However, recent work (Antelmann et al., 2007) gave surprising results showing that phytases were not induced under phosphate starvation conditions or by phytate addition. However, re-distribution of the major cell wall protease WprA from the cell wall to the extracellular medium in phytate-supplemented medium was observed. It was concluded that phytate is an alternative phosphorus source allowing B. subtilis cells to overcome phosphate starvation.

\section{CONCLUDING REMARKS}

In conclusion, the compounds produced by Bacillus spp. presented above and, what is more important, targets of their action are various and broad. There are many known pathogens, parasites of plants causing large losses in the agriculture. It is promising that many of them have antagonists in the Bacillus genus. Commercially available spores of beneficial bacteria and the development of plants genetically modified with genes from the Bacillus genome give advantage to scientists and farmers over the plant pathogens. But it seems that the war is not over. Evolution of resistance in targeted pests is the most pressing problem (Zhao et al., 2005) and needs to be solved as soon as possible. Bacteria from the Bacillus genus posses an additional property, profitable from the technological point of view. They form spores, whose effectiveness in the fight against phytopathogenic competitors is worth further researches. This is so because the spores are extremely resistant and stable which means that they can remain viable in spite of a long period of storage. Apart from the listed advantages, we should pay attention to the fact that spores can be produced in a relatively easy and inexpensive way (Ongena et al., 2004).

\section{Acknowledgements}

This work was supported by the Ministry of Science and Higher Education grant no. PBZ-KBN112/P06/2005.

\section{REFERENCES}

Adebanjo A, Bankole SA (2004) Evaluation of some fungi and bacteria for biocontrol of anthracnose disease of cowpea. J Basic Microbiol 44: 3-9.

Andersen JB, Koch B, Nielsen TH, Sorensen D, Hansen M, Nybroe O, Christophersen C, Sorensen J, Molin S, Givskov M (2003) Surface motility in Pseudomonas sp. DSS73 is required for efficient biological containment of the root-pathogenic microfungi Rhizoctonia solani and Pythium ultimum. Microbiology 149: 37-46.

Antelmann H, Towe S, Albrecht D, Hecker M (2007) The phosphorus source phytate changes the composition of the cell wall proteome in Bacillus subtilis. J Proteome Res 6: 897-903.

Bacon CW, Yates IE, Hinton DM, Meredith F (2001) Biological control of Fusarium moniliforme in maize. Environ Health Perspect 109: 325-332.

Bais HP, Fall R, Vivanco JM (2004) Biocontrol of Bacillus subtilis against infection of Arabidopsis roots by Pseudomonas syringae is facilitated by biofilm formation and surfactin production. Plant Physiol 134: 307-319.

Bees MA, Andresen P, Mosekilde E, Givskov M (2000) The interaction of thin-film flow, bacterial swarming and cell differentiation in colonies of Serratia liquefaciens. J Math Biol 40: 27-63.

Benhamou N, Kloepper JW, Quadt-Hallman A, Tuzun S (1996) Induction of defense-related ultrastructural modifications in pea root tissues inoculated with endophytic bacteria. Plant Physiol 112: 919-929.

Bianciotto V, Andreotti S, Balestrini R, Bonfante P, Perotto S (2001) Mucoid mutants of the biocontrol strain Pseudomonas fluorescens CHA0 show increased ability in biofilm formation on mycorrhizal and nonmycorrhizal carrot roots. Mol Plant Microbe Interact 14: 255-260.

Branda SS, Gonzalez-Pastor JE, Ben-Yehuda S, Losick R, Kolter R (2001) Fruiting body formation by Bacillus subtilis. Proc Natl Acad Sci USA 98: 11621-11626.

Calvio C, Celandroni F, Ghelardi E, Amati G, Salvetti S, Ceciliani F, Galizzi A, Senesi S (2005) Swarming differentiation and swimming motility in Bacillus subtilis are controlled by $s w r A$, a newly identified dicistronic operon. J Bacteriol 187: 5356-5366.

Carrillo C, Teruel JA, Aranda FJ, Ortiz A (2003) Molecular mechanism of membrane permeabilization by the peptide antibiotic surfactin. Biochim Biophys Acta Biomembr 1611: 91-97.

Cavaglieri L, Passone A, Etcheverry M (2004) Screening procedures for selecting rhizobacteria with biocontrol effects upon Fusarium verticillioides growth and fumonisin B1 production. Res Microbiol 155: 747-754.

Cavaglieri L, Orlando J, Etcheverry M (2005) In vitro influence of bacterial mixtures on Fusarium verticillioides growth and fumonisin B1 production: effect of seeds treatment on maize root colonization. Lett Appl Microbiol 41: 390-396.

Chen WL, Gong HF, Lin FC, Xu JP, Li DB (1997) The antagonistic activities of Bacillus subtilis A30 to rice pathogens. J Zhejiang Agricul Univ 23: 649-654.

Connelly MB, Young GM, Sloma A (2004) Extracellular proteolytic activity plays a central role in swarming motility in Bacillus subtilis. J Bacteriol 186: 4159-4167.

Cosby WM, Vollenbroich D, Lee OH, Zuber P (1998) Altered srf expression in Bacillus subtilis resulting from changes in culture $\mathrm{pH}$ is dependent on the Spo0K oligopeptide permease and the ComQX system of extracellular control. J Bacteriol 180: 1438-1445.

Danhorn T, Fuqua C (2007) Biofilm formation by plant-associated bacteria. Annu Rev Microbiol 61: 401-422. 
El-Ghaouth A (1997) Biologically-based alternatives to synthetic fungicides for the control of postharvest diseases. J Ind Microbiol Biotechnol 19: 160-162.

Finking R, Marahiel MA (2004) Biosynthesis of nonribosomal peptides 1. Annu Rev Microbiol 58: 453-488.

Földes T, Bánhegyi I, Herpai Z, Varga L, Szigeti J (2000) Isolation of Bacillus strains from the rhizosphere of cereals and in vitro screening for antagonism against phytopathogenic, food-borne pathogenic and spoilage micro-organisms. J Appl Microbiol 89: 840-846.

Grangemard I, Peypoux F, Wallach J, Das BC, Labbe H, Caille A, Genest M, Maget-Dana R, Ptak M, Bonmatin JM (1997) Lipopeptides with improved properties: structure by NMR, purification by HPLC and structureactivity relationships of new isoleucyl-rich surfactins. J Pept Sci 3: 145-154.

Greiner R, Haller E, Konietzny U, Jany KD (1997) Purification and characterization of a phytase from Klebsiella terrigena. Arch Biochem Biophys 341: 201-206.

Heerklotz H, Seelig J (2007) Leakage and lysis of lipid membranes induced by the lipopeptide surfactin. Eur Biophys J 36: 305-314.

Hiradate S, Yoshida S, Sugie H, Yada H, Fujii Y (2002) Mulberry anthracnose antagonists (iturins) produced by Bacillus amyloliquefaciens RC-2. Phytochemistry 61: 693-698.

Hou X, Boyetchko SM, Brkic M, Olson D, Ross A, Hegedus D (2006) Characterization of the anti-fungal activity of a Bacillus spp. associated with sclerotia from Sclerotinia sclerotiorum. Appl Microbiol Biotechnol 72: 644-653.

Idriss EE, Makarewicz O, Farouk A, Rosner K, Greiner R, Bochow H, Richter T, Borriss R (2002) Extracellular phytase activity of Bacillus amyloliquefaciens FZB45 contributes to its plant-growth-promoting effect. Microbiology 148: 2097-2109.

Izquierdo L, Abitiu N, Coderch N, Hita B, Merino S, Gavin R, Tomás JM, Regué M (2002) The inner-core lipopolysaccharide biosynthetic waaE gene: function and genetic distribution among some Enterobacteriaceae. Microbiology 148: 3485-3496.

Jeleń F, Oleksy A, Smietana K, Otlewski J (2003) PDZ domains - common players in the cell signaling. Acta Biochim Polon 50: 985-1017.

Julkowska D, Obuchowski M, Holland IB, Seror SJ (2004) Branched swarming patterns on a synthetic medium formed by wild-type Bacillus subtilis strain 3610: detection of different cellular morphologies and constellations of cells as the complex architecture develops. Microbiology 150: 1839-1849.

Julkowska D, Obuchowski M, Holland IB, Seror SJ (2005) Comparative analysis of the development of swarming communities of Bacillus subtilis 168 and a natural wild type: critical effects of surfactin and the composition of the medium. J Bacteriol 187: 65-76.

Kawulka KE, Sprules T, Diaper CM, Whittal RM, McKay RT, Mercier P, Zuber P, Vederas JC (2004) Structure of subtilosin A, a cyclic antimicrobial peptide from Bacillus subtilis with unusual sulfur to alpha-carbon crosslinks: formation and reduction of alpha-thio-alpha-amino acid derivatives. Biochemistry 43: 3385-3395.

Kearns DB, Losick R (2003) Swarming motility in undomesticated Bacillus subtilis. Mol Microbiol 49: 581-590.

Kearns DB, Chu F, Rudner R, Losick R (2004) Genes governing swarming in Bacillus subtilis and evidence for a phase variation mechanism controlling surface motility. Mol Microbiol 52: 357-369.

Kerovuo J, Lauraeus M, Nurminen P, Kalkkinen N, Apajalahti J (1998) Isolation, characterization, molecular gene cloning, and sequencing of a novel phytase from Bacillus subtilis. Appl Environ Microbiol 64: 2079-2085.

Kim YO, Lee JK, Kim HK, Yu JH, Oh TK (1998) Cloning of the thermostable phytase gene (phy) from Bacillus sp. DS11 and its overexpression in Escherichia coli. FEMS Microbiol Lett 162: 185-191.

Kim PI, Chung KC (2004) Production of an antifungal protein for control of Colletotrichum lagenarium by Bacillus amyloliquefaciens MET0908. FEMS Microbiol Lett 234: 177-183.

Kinsinger RF, Shirk MC, Fall R (2003) Rapid surface motility in Bacillus subtilis is dependent on extracellular surfactin and potassium ion. J Bacteriol 185: 5627-5631.

Kloepper JW, Leong J, Teintze M, Schroth MN (1980) Enhanced plant growth by siderophores produced by plant growth-promoting rhizobacteria. Nature 286: 885-886.

Kowall M, Vater J, Kluge B, Stein T, Franke P, Ziessow D (1998) Separation and characterization of surfactin isoforms produced by Bacillus subtilis OKB 105 J Colloid Interface Sci 204: 1-8.

Kraus J, Loper JE (1995) Characterization of a genomic region required for production of the antibiotic pyoluteorin by the biological control agent Pseudomonas fluorescens Pf-5. Appl Environ Microbiol 61: 849-854.

Kunst F, Ogasawara N, Moszer I, Albertini AM, Alloni G, Azevedo V, Bertero MG, Bessieres P, Bolotin A, Borchert S, Borriss R, Boursier L, Brans A, Braun M, Brignell SC, Bron S, Brouillet S, Bruschi CV, Caldwell B, Capuano V, Carter NM, Choi SK, Codani JJ, Connerton IF, Danchin A (1997) The complete genome sequence of the gram-positive bacterium Bacillus subtilis. Nature 390: 249-256.

Leclere V, Bechet M, Adam A, Guez JS, Wathelet B, Ongena $\mathrm{M}$, Thonart $\mathrm{P}$, Gancel $\mathrm{F}$, Chollet-Imbert $\mathrm{M}$, Jacques $\mathrm{P}$ (2005) Mycosubtilin overproduction by Bacillus subtilis BBG100 enhances the organism's antagonistic and biocontrol activities. Appl Environ Microbiol 71: 4577-4584.

Leclere V, Marti R, Bechet M, Fickers P, Jacques P (2006) The lipopeptides mycosubtilin and surfactin enhance spreading of Bacillus subtilis strains by their surface-active properties. Arch Microbiol 186: 475-483.

Leroux P (2003) Modes of action of agrochemicals against plant pathogenic organisms. C R Biol 326: 9-21.

Lim JH, Park BK, Kim MS, Hwang MH, Rhee MH, Park SC, Yun HI (2005) The anti-thrombotic activity of surfactins. J Vet Sci 6: 353-355.

Li B, Xie GL, Soad A, Coosemans J (2005) Suppression of Meloidogyne javanica by antagonistic and plant growthpromoting rhizobacteria. J Zhejiang Univ Sci B 6: 496501.

Lin D, Qu LJ, Gu H, Chen Z (2001) A 3.1-kb genomic fragment of Bacillus subtilis encodes the protein inhibiting growth of Xanthomonas oryzae pv. oryzae. J Appl Microbiol 91: 1044-1050.

Liu JY, Liu W, Pan NS, Chen ZL (1991) The characterization of antagonistic bacterium A014 and its antibacterial protein. Acta Botanica Sinica 33: 157-161.

Liu J, Liu M, Wang J, Yao JM, Pan RR, Yu ZL (2005) Enhancement of the Gibberella zeae growth inhibitory lipopeptides from a Bacillus subtilis mutant by ion beam implantation. Appl Microbiol Biotechnol 69: 223-228.

Madhaiyan M, Suresh Reddy BV, Anandham R, Senthilkumar M, Poonguzhali S, Sundaram SP, Sa T (2006) Plant growth-promoting Methylobacterium induces defense responses in groundnut (Arachis hypogaea L.) compared with rot pathogens. Curr Microbiol 53: 270-276. 
Maget-Dana R, Peypoux F (1994) Iturins, a special class of pore-forming lipopeptides: biological and physicochemical properties. Toxicology 87: 151-174.

Manjula K, Podile AR (2001) Chitin-supplemented formulations improve biocontrol and plant growth promoting efficiency of Bacillus subtilis AF 1. Can J Microbiol 47: 618-625.

Manjula K, Kishore GK, Podile AR (2004) Whole cells of Bacillus subtilis AF 1 proved more effective than cellfree and chitinase-based formulations in biological control of citrus fruit rot and groundnut rust. Can J Microbiol 50: 737-744.

Marten P, Smalla K, Berg G (2000) Genotypic and phenotypic differentiation of an antifungal biocontrol strain belonging to Bacillus subtilis. J Appl Microbiol 89: 463471.

Matsuyama T, Kaneda K, Nakagawa Y, Isa K, Hara-Hotta H, Yano I (1992) A novel extracellular cyclic lipopeptide which promotes flagellum-dependent and -independent spreading growth of Serratia marcescens. J Bacteriol 74: 1769-1776.

Maugenest S, Martinez I, Godin B, Perez P, Lescure AM (1999) Structure of two maize phytase genes and their spatio-temporal expression during seedling development. Plant Mol Biol 39: 503-514.

Mireles JR, Toguchi A, Harshey RM (2001) Salmonella enterica serovar typhimurium swarming mutants with altered biofilm-forming abilities: surfactin inhibits biofilm formation. J Bacteriol 183: 5848-5854.

Mizumoto S, Hirai M, Shoda M (2006) Production of lipopeptide antibiotic iturin A using soybean curd residue cultivated with Bacillus subtilis in solid-state fermentation. Appl Microbiol Biotechnol 72: 869-875.

Morikawa M (2006) Beneficial biofilm formation by industrial bacteria Bacillus subtilis and related species. J Biosci Bioeng 101: 1-8.

Moszer I (1998) The complete genome of Bacillus subtilis: from sequence annotation to data management and analysis. FEBS Lett 430: 28-36.

Mulligan CN (2005) Environmental applications for biosurfactants. Environ Pollut 133: 183-198.

Munimbazi C, Bullerman LB (1998) Isolation and partial characterization of antifungal metabolites of Bacillus pumilus. J Appl Microbiol 84: 959-968.

Murudkar CS, Kodgire P, Krishnamurthy Rao K (2006) The carboxy terminal domain of Epr, a minor extracellular serine protease, is essential for the swarming motility of Bacillus subtilis. FEMS Microbiol Lett 257: 24-31.

Nakano MM, Corbell N, Besson J, Zuber P (1992) Isolation and characterization of $s f p$ : a gene that functions in the production of the lipopeptide biosurfactant, surfactin, in Bacillus subtilis. Mol Gen Genet 232: 313-321.

Naruse N, Tenmyo O, Kobaru S, Kamei H, Miyaki T, Konishi M, Oki T (1990) Pumilacidin, a complex of new antiviral antibiotics. Production, isolation, chemical properties, structure and biological activity. I Antibiot (Tokyo) 43: 267-280.

Nielsen TH, Sorensen D, Tobiasen C, Andersen JB, Christophersen C, Givskov M, Sorensen J (2002) Antibiotic and biosurfactant properties of cyclic lipopeptides produced by fluorescent Pseudomonas spp. from the sugar beet rhizosphere. Appl Environ Microbiol 68: 3416-3423.

Okigbo RN (2005) Biological control of postharvest fungal rot of yam (Dioscorea spp.) with Bacillus subtilis. Mycopathologia 159: 307-314.

Ongena M, Duby F, Rossignol F, Fauconnier ML, Dommes J, Thonart P (2004) Stimulation of the lipoxygenase pathway is associated with systemic resistance induced in bean by a nonpathogenic Pseudomonas strain. Mol Plant Microbe Interact 17: 1009-1018.

Ongena M, Duby F, Jourdan E, Beaudry T, Jadin V, Dommes J, Thonart P (2005a) Bacillus subtilis M4 decreases plant susceptibility towards fungal pathogens by increasing host resistance associated with differential gene expression. Appl Microbiol Biotechnol 67: 692-698.

Ongena M, Jacques P, Toure Y, Destain J, Jabrane A, Thonart $P$ (2005b) Involvement of fengycin-type lipopeptides in the multifaceted biocontrol potential of Bacillus subtilis. Appl Microbiol Biotechnol 69: 29-38.

Ongena M, Jourdan E, Adam A, Paquot M, Brans A, Joris B, Arpigny JL, Thonart P (2007) Surfactin and fengycin lipopeptides of Bacillus subtilis as elicitors of induced systemic resistance in plants. Environ Microbiol 9: 10841090.

Pandey A, Palni LM (1997) Bacillus species: the dominant bacteria of the rhizosphere of established tea bushes. Microbiol Res 152: 359-365.

Park RY, Sun HY, Choi MH, Bai YH, Chung YY, Shin SH (2006) Proteases of a Bacillus subtilis clinical isolate facilitate swarming and siderophore-mediated iron uptake via proteolytic cleavage of transferrin. Biol Pharm Bull 29: 850-853.

Peypoux F, Bonmatin JM, Wallach J (1999) Recent trends in the biochemistry of surfactin. Appl Microbiol Biotechnol 51: 553-563.

Priest FG (1993) Systematics and ecology of Bacillus. In Bacillus subtilis and other gram positive bacteria: biochemistry, physiology, and molecular genetics (Sonenshein AL, Hoch JA, Losick R, eds) pp 3-16. American Society for Microbiology. Washington D.C.

Przestalski S, Sarapuk J, Kleszczyńska H, Gabrielska J, Hladyszowski J, Trela Z, Kuczera J (2000) Influence of amphiphilic compounds on membranes. Acta Biochim Polon 47: 627-638.

Raupach GS, Kloepper JW (1998) Mixtures of plant growthpromoting rhizobacteria enhance biological control of multiple cucumber pathogens. Phytopathology 88: 11581164.

Ren D, Sims JJ, Wood TK (2002) Inhibition of biofilm formation and swarming of Bacillus subtilis by (5Z)-4-bromo-5-(bromomethylene)-3-butyl-2(5H)-furanone. Lett Appl Microbiol 34: 293-299.

Richardson AE, Hadobas PA (1997) Soil isolates of Pseudomonas spp. that utilize inositol phosphates. Can J Microbiol 43: 509-516.

Richardson AE, Hadobas PA, Hayes JE (2001) Extracellular secretion of Aspergillus phytase from Arabidopsis roots enables plants to obtain phosphorus from phytate. Plant J 25: 641-649.

Romero D, de Vicente A, Rakotoaly RH, Dufour SE, Veening JW, Arrebola E, Cazorla FM, Kuipers OP, Paquot M, Perez-Garcia A (2007) The iturin and fengycin families of lipopeptides are key factors in antagonism of Bacillus subtilis toward Podosphaera fusca. Mol Plant Microbe Interact 20: 430-440.

Ron EZ, Rosenberg E (2001) Natural roles of biosurfactants. Environ Microbiol 3: 229-236.

Shapiro JA (1998) Thinking about bacterial population as multicellular organisms. Annu Rev Microbiol 52: 63086321.

Sieber SA, Marahiel MA (2003) Learning from nature's drug factories: nonribosomal synthesis of macrocyclic peptides. J Bacteriol 185: 7036-7043.

Singh P, Cameotra SS (2004) Potential applications of microbial surfactants in biomedical sciences. Trends Biotechnol 22: 142-146. 
Sharga BM, Lyon GD (1998) Bacillus subtilis BS 107 as an antagonist of potato blackleg and soft rot bacteria. Can J Microbiol 44: 777-783.

Souto GI, Correa OS, Montecchia MS, Kerber NL, Pucheu NL, Bachur M, Garcia AF (2004) Genetic and functional characterization of a Bacillus sp. strain excreting surfactin and antifungal metabolites partially identified as iturin-like compounds. J Appl Microbiol 97: 1247-1256.

Stein T, Borchert S, Conrad B, Feesche J, Hofemeister B, Hofemeister J, Entian KD (2002) Two different antibiotic-like peptides originate from the ericin gene cluster of Bacillus subtilis A1/3. J Bacteriol 184: 1703-1711.

Stein T (2005) Bacillus subtilis antibiotics: structures, syntheses and specific functions. Mol Microbiol 56: 845-857.

Stover AG, Driks A (1999) Secretion, localization, and antibacterial activity of TasA, a Bacillus subtilis spore-associated protein. J Bacteriol 181: 1664-1672.

Symmank H, Franke P, Saenger W, Bernhard F (2002) Modification of biologically active peptides: production of a novel lipohexapeptide after engineering of Bacillus subtilis surfactin synthetase. Protein Eng 15: 913-921.

Thennarasu S, Lee DK, Poon A, Kawulka KE, Vederas JC, Ramamoorthy A (2005) Membrane permeabilization, orientation, and antimicrobial mechanism of subtilosin A. Chem Phys Lipids 137: 38-51.

Thimon L, Peypoux F, Maget-Dana R, Roux B, Michel G (1992) Interactions of bioactive lipopeptides, iturin A and surfactin from Bacillus subtilis. Biotechnol Appl Biochem 16: 144-151.

Thimon L, Peypoux F, Exbrayat JM, Michel G (1994) Effect of iturin A, a lipopeptide from Bacillus subtilis on morphology and ultrastructure of human erythrocytes. Cytobios 79: 69-83.

Timmusk S, Grantcharova N, Wagner EG (2005) Paenibacillus polymyxa invades plant roots and forms biofilms. Appl Environ Microbiol 71: 7292-7300.

Toguchi A, Siano M, Burkart M, Harshey RM (2000) Genetics of swarming motility in Salmonella enterica serovar typhimurium: critical role for lipopolysaccharide. J Bacteriol 182: 6308-6321.

Toure Y, Ongena M, Jacques P, Guiro A, Thonart P (2004) Role of lipopeptides produced by Bacillus subtilis GA1 in the reduction of grey mould disease caused by Botrytis cinerea on apple. J Appl Microbiol 96: 1151-1160.

Tsuge K, Ano T, Hirai M, Nakamura Y, Shoda M (1999) The genes $d e g Q, p p s$, and $l p a-8(s f p)$ are responsible for conversion of Bacillus subtilis 168 to plipastatin production. Antimicrob Agents Chemother 43: 2183-2192.

Tsuge K, Inoue S, Ano T, Itaya M, Shoda M (2005) Horizontal transfer of iturin A operon, itu, to Bacillus subtilis 168 and conversion into an iturin A producer. Antimicrob Agents Chemother 49: 4641-4648.

Tye AJ, Siu FK, Leung TY, Lim BL (2002) Molecular cloning and the biochemical characterization of two novel phytases from Bacillus subtilis 168 and Bacillus licheniformis. Appl Microbiol Biotechnol 59: 190-197.

Van Loon LC, Bakker PAHM, Pietrase CMJ (1998) Systemic resistance induced by rhizosphere bacteria. Annu Rev Phytopathol 36: 453-483.

Vullo DL, Coto CE, Siñeriz F (1991) Characteristics of an inulinase produced by Bacillus subtilis 430A, a strain isolated from the rhizosphere of Vernonia herbacea (Vell Rusby). Appl Environ Microbiol 57: 2392-2394.

Walker R, Ferguson CMJ, Booth NA, Allan EJ (2002) The symbiosis of Bacillus subtilis L-forms with Chinese cabbage seedlings inhibits conidial germination of Botrytis cinerea. Lett Appl Microbiol 34: 42-45.

Wyss M, Brugger R, Kronenberger A, Rémy R, Fimbel R, Oesterhelt G, Lehmann M, van Loon AP (1999) Biochemical characterization of fungal phytases (myo-inositol hexakisphosphate phosphohydrolases): catalytic properties. Appl Environ Microbiol 65: 367-373.

Yakimov MM, Fredrickson HL, Timmis KN (1996) Effect of heterogeneity of hydrophobic moieties on surface activity of lichenysin A, a lipopeptide biosurfactant from Bacillus licheniformis BAS50. Biotechnol Appl Biochem 23: 13-18.

Yu GY, Sinclair JB, Hartman GL, Bertagnolli BL (2002) Production of iturin A by Bacillus amyloliquefaciens supressing Rhizoctonia solani. Soil Biol Biochem 34: 955-963.

Zhang X, Zhang BX, Zhang Z, Shen WF, Yang CH, Yu JQ, Zhao YH (2005) Survival of the biocontrol agents Brevibacillus brevis ZJY-1 and Bacillus subtilis ZJY-116 on the spikes of barley in the field. J Zhejiang Univ Sci B 6: 770-777.

Zhao JZ, Cao J, Collins HL, Bates SL, Roush RT, Earle ED, Shelton AM (2005) Concurrent use of transgenic plants expressing a single and two Bacillus thuringiensis genes speeds insect adaptation to pyramided plants. Proc Natl Acad Sci USA 102: 8426-8430. 